Open Access

Res. Agric. Livest. Fish.

Research Article

Vol. 2, No. 2, August 2015: 221-228

\title{
NITROGEN MINERALIZATION OF BIOSLURRY AND OTHER MANURES IN SOIL
}

\author{
M. Asadul Haque ${ }^{1 *}$, M. Jahiruddin ${ }^{2}$, M. Mazibur Rahman ${ }^{2}$ and M. Abu Saleque ${ }^{3}$ \\ ${ }^{1}$ Department of Soil Science, Patuakhali Science and Technology University, Patuakhali; \\ ${ }^{2}$ Department of Soil Science, Bangladesh Agricultural University, Mymensingh-2202; \\ ${ }^{3}$ Bangladesh Rice Research Institute, Gazipur, Bangladesh \\ *Corresponding author: M. Asadul Haque, E-mail: masadulh@yahoo.com
}

\section{ARTICLE INFO \\ ABSTRACT}

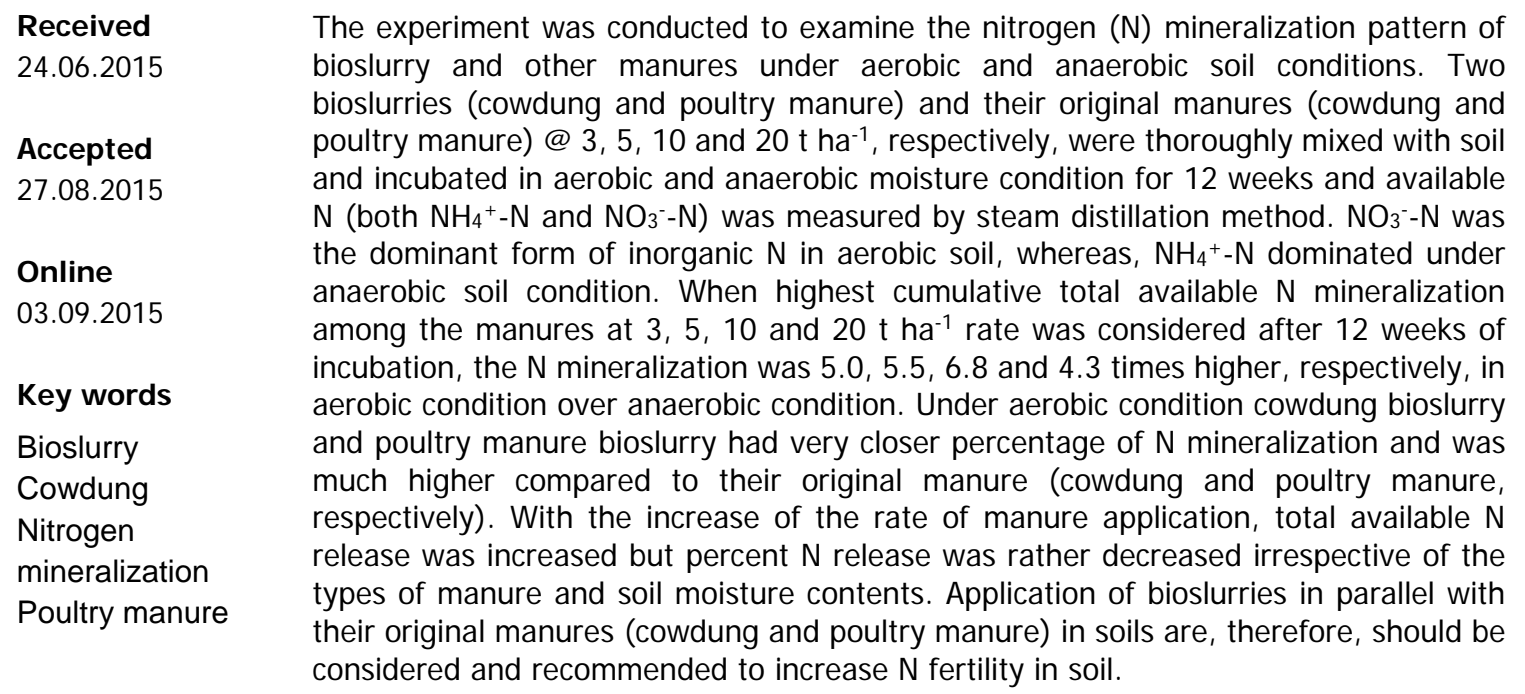

To cite this article: MA Haque, M Jahiruddin, MM Rahman and MA Saleque, 2015. Nitrogen mineralization of bioslurry and other manures in soil. Res. Agric. Livest. Fish. 2 (2): 221-228.

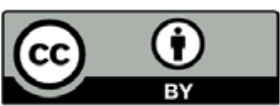

This is an open access article licensed under the terms of the

Creative Commons Attribution 4.0 International License

www.agroaid-bd.org/ralf, E-mail: editor.ralf@gmail.com 


\section{INTRODUCTION}

Intensive cultivation of high yielding crop varieties using only inorganic fertilizers and almost no recycling of organic residues have reduced soil organic carbon as well as other plant nutrients, especially N, which leads to severe land degradation in Bangladesh (Karim et al., 1994; Rahman, 2010). Nitrogen deficiency appeared as a great concern in the intensively cultivated areas due to lack of proper soil management by incorporating organic manures (Karim et al., 1994). Because of hyperthermic temperature regime, the rate of organic matter mineralization in soils of Bangladesh is usually very high, which affect nitrogen dynamics in soils (Rahman 2014).

Among different organic materials, poultry manure, and cowdung are used for crop production in Bangladesh. Recently in Bangladesh, biogas technology has been introduced to meet the energy crisis and installed more than 31,000 biogas plants by the year 2013. The bioslurry produced from these biogas digesters is mostly being wastage due to its liquid state; farmers are not taking care of the disposal of the bioslurry and thus it polluting the environment many cases (Islam, 2011). If properly managed, bioslurry could play a major role in supplementing the use of expensive chemical fertilizers (Yu et al., 2010; Abubaker, 2012) in Bangladesh. Nutrient mineralization patterns of organic residues like cowdung, poultry manure or bioslurries are variable depending on the chemical composition (Chaudhary et al., 2014).There also have some differences in the mineralization of organic manures under aerobic and anaerobic conditions. Despite recent literature provides valuable information on many aspects of $\mathrm{N}$ mineralization, the interaction between the kind of organic manures and $\mathrm{N}$ mineralization under aerobic and anaerobic conditions is not well understood. The present paper compares the $\mathrm{N}$ mineralization pattern in the bioslurries and other manure amended soils under aerobic and anaerobic conditions.

\section{MATERIALS AND METHODS}

The incubation experiment was conducted in the Department of Soil Science, Bangladesh Agricultural University (BAU), Mymensingh. Soils were collected from the BAU farm (Old Brahmaputra Floodplain, AEZ-9) at $0-15 \mathrm{~cm}$ depth of a field and were thoroughly mixed. The soils were spread on brown paper for air-drying. The air-dry soils were ground and passed through a 2-mm sieve to remove roots and other debris. The soil was silt loam, with $1.14 \%$ O.C., $6.5 \mathrm{pH}, 1.17 \%$ total N, $6.0 \mathrm{mg} \mathrm{kg}^{-1}$ available $\mathrm{P}, 0.12 \mathrm{cmol} \mathrm{kg}^{-1}$ exchangeable $\mathrm{K}$, and $14.0 \mathrm{mg} \mathrm{kg}^{-1}$ available $\mathrm{S}$. The elements were determined by standard methods as outlined by Page et al., (1982). Four types of organic manure viz. cowdung, cowdung bioslurry, poultry manure and poultry manure bioslurry were used in this study. The manures were air-dried, ground and passed through a 2-mm sieve. The chemical composition of various manures is presented in Table 1.

Table 1. Chemical composition of different manures

\begin{tabular}{lccccccccc}
\hline Manure & $\mathbf{C}(\%)$ & $\mathbf{N}(\%)$ & $\mathbf{P}(\%)$ & $\mathbf{K}(\%)$ & $\mathbf{S}(\%)$ & $\mathbf{C : N}$ & $\mathbf{C : P}$ & $\mathbf{C : K}$ & $\mathbf{C : S}$ \\
\hline Cowdung (CD) & 38.6 & 1.70 & 0.88 & 2.02 & 0.41 & 22.8 & 43.8 & 19.1 & 95.3 \\
CD bioslurry & 29.3 & 1.84 & 1.30 & 0.93 & 0.42 & 16.0 & 22.6 & 31.6 & 69.4 \\
Poultry manure (PM) & 34.9 & 2.28 & 1.48 & 2.23 & 0.53 & 15.3 & 23.5 & 15.6 & 65.7 \\
PM bioslurry & 19.2 & 1.70 & 2.52 & 0.67 & 0.67 & 11.3 & 7.6 & 28.5 & 28.5 \\
\hline
\end{tabular}

An amount of $100 \mathrm{~g}$ air-dry soil was weighed into a series of small plastic containers. Air dry finely ground partially decomposed cowdung, cowdung bioslurry, poultry manure and poultry manure bioslurry @ 1.5, 2.5, 5.0 and $10.0 \mathrm{~g} \mathrm{~kg}^{-1}$ soil (equivalent to 3, 5, 10 and $20 \mathrm{t} \mathrm{ha}^{-1}$, respectively) were thoroughly mixed with soil in separate containers. A control container (without organic manure) was placed along with each set of incubation. Two moisture levels - one field capacity/aerobic ( $25 \%$ soil moisture) and another submerged/anaerobic condition $(1 \mathrm{~cm}$ standing water above soil level) were maintained. The containers were incubated at room temperature $\left(25 \pm 2^{\circ} \mathrm{C}\right)$ for 12 weeks. All the treatments were replicated twice. 
Every week soil moisture contents were monitored. The weight loss due to evaporation of moisture was replenished by adding required amount of water and was mixed with soil properly to maintain specific moisture content (field capacity and saturated condition) of the soil. Destructive sampling was done in this experiment. The first sampling and followed by measurement was done just the next day of incubation and the second measurement was done at 7 days after incubation; thereafter at 7-day intervals and after 8 weeks measurement was done at 2-week intervals. Available $\mathrm{N}$ content of soil was extracted (1:10 soil-extractant ratio) by $2 \mathrm{M} \mathrm{KCl}$ solution (Keeney and Nelson, 1982). The aliquot was steam distilled with MgO and Devarda's alloy to determine available $\mathrm{NH}_{4}{ }^{+}-\mathrm{N}$ and $\mathrm{NO}_{3}-\mathrm{N}$ contents. The data were corrected for moisture content and reported on oven dry basis.

Table 2. Maximum release of total available $\mathrm{N}$ from different sources of organic manures under aerobic and anaerobic soil conditions

\begin{tabular}{|c|c|c|c|c|c|}
\hline \multirow[t]{2}{*}{ Types of manure } & \multirow[t]{2}{*}{$\mathrm{N}$ added $\left(\mathrm{mg} \mathrm{kg}^{-1}\right)$} & \multicolumn{2}{|c|}{$\begin{array}{l}\text { Maximum total available } \mathrm{N} \\
\text { release }\left(\mathrm{mg} \mathrm{kg}^{-1}\right)\end{array}$} & \multicolumn{2}{|c|}{$\%$ release of added $\mathrm{N}$} \\
\hline & & Aerobic & Anaerobic & Aerobic & Anaerobic \\
\hline \multicolumn{6}{|c|}{ Manure rate: $3 \mathrm{t} \mathrm{ha}^{-1}$} \\
\hline Cowdung & 25.5 & 17 & 4.5 & 66.7 & 17.6 \\
\hline Cowdung bioslurry & 27.6 & 23.8 & 6.0 & 86.2 & 21.7 \\
\hline Poultry manure & 34.2 & 21.9 & 7.4 & 64.0 & 21.6 \\
\hline Poultry manure bioslurry & 25.5 & 21.5 & 5.5 & 84.3 & 21.6 \\
\hline \multicolumn{6}{|c|}{ Manure rate: $5 \mathrm{t} \mathrm{ha}^{-1}$} \\
\hline Cowdung & 42.5 & 19.0 & 6.3 & 44.7 & 14.8 \\
\hline Cowdung bioslurry & 46.0 & 27.6 & 5.7 & 60.0 & 12.4 \\
\hline Poultry manure & 57.0 & 30.9 & 7.7 & 54.2 & 13.5 \\
\hline Poultry manure bioslurry & 42.5 & 23.9 & 5.3 & 56.2 & 12.5 \\
\hline \multicolumn{6}{|c|}{ Manure rate: $10 \mathrm{t} \mathrm{ha}^{-1}$} \\
\hline Cowdung & 85.0 & 33.6 & 5.4 & 39.5 & 6.4 \\
\hline Cowdung bioslurry & 92.0 & 42.3 & 8.5 & 46.0 & 9.2 \\
\hline Poultry manure & 114.0 & 33.8 & 12.0 & 29.6 & 10.5 \\
\hline Poultry manure bioslurry & 85.0 & 41.3 & 7.0 & 48.6 & 8.2 \\
\hline \multicolumn{6}{|c|}{ Manure rate: $20 \mathrm{t} \mathrm{ha}^{-1}$} \\
\hline Cowdung & 170 & 28.2 & 7.7 & 16.6 & 4.5 \\
\hline Cowdung bioslurry & 184 & 49.7 & 10.7 & 27.0 & 5.8 \\
\hline Poultry manure & 228 & 38.6 & 16.3 & 16.9 & 7.1 \\
\hline Poultry manure bioslurry & 170 & 47.6 & 8.9 & 28.0 & 5.2 \\
\hline
\end{tabular}

\section{RESULTS AND DISCUSSION}

\section{$\mathrm{NH}_{4}{ }^{+}-\mathrm{N}$ mineralization}

The $\mathrm{NH}_{4}{ }^{+}-\mathrm{N}$ mineralization was varied by manure types (cowdung, cowdung bioslurry, poultry manure and poultry manure bioslurry), manure rates $\left(3,5,10\right.$ and $\left.20 \mathrm{t} \mathrm{ha}^{-1}\right)$, soil moisture (aerobic and anaerobic conditions) and incubation time. The extent of $\mathrm{NH}_{4}{ }^{+}-\mathrm{N}$ mineralization of different manures under aerobic and anaerobic conditions is presented in Fig. 1. Poultry manure had the highest release of $\mathrm{NH}_{4}{ }^{+}-\mathrm{N}$ showing an amount of 4.4 (Fig. 1a), 5.6 (Fig. 1c) and 6.9 (Fig. 1e) $\mathrm{mg} \mathrm{kg}^{-1}$ soil against the manure rate at 3, 5 and $10 \mathrm{t} \mathrm{ha}^{-1}$, respectively, under aerobic condition, and 6.3 (Fig. 1b), 7.7 (Fig. 1d), 12.0 (Fig. 1f) and 16.3 (Fig. 1h) $\mathrm{mg} \mathrm{kg}^{-1}$ soil at 3, 5, 10 and $20 \mathrm{t} \mathrm{ha}^{-1}$ rates, respectively, under anaerobic condition. The highest mineralization $\left(7.9 \mathrm{mg} \mathrm{kg}^{-1}\right)$ at $20 \mathrm{t} \mathrm{ha}$ ${ }^{1}$ rate in aerobic condition (Fig. 1g) was recorded by poultry manure bioslurry. Comparing the $\mathrm{NH}_{4}{ }^{+}-\mathrm{N}$ mineralization between aerobic and anaerobic conditions, it appeared that at all manure application rates, anaerobic condition demonstrated 50,52, 74 and 106\% higher $\mathrm{NH}_{4}{ }^{+}-\mathrm{N}$ mineralization over aerobic conditions at $3,5,10$ and $20 \mathrm{t} \mathrm{ha}^{-1}$ manure application rates, respectively. This result was highly expected since $\mathrm{N}$ mineralization under anaerobic condition stops at ammonification stage due to lack of $\mathrm{O}_{2}$ to carry out nitrification (Brady and Weil, 2013). 
Aerobic condition
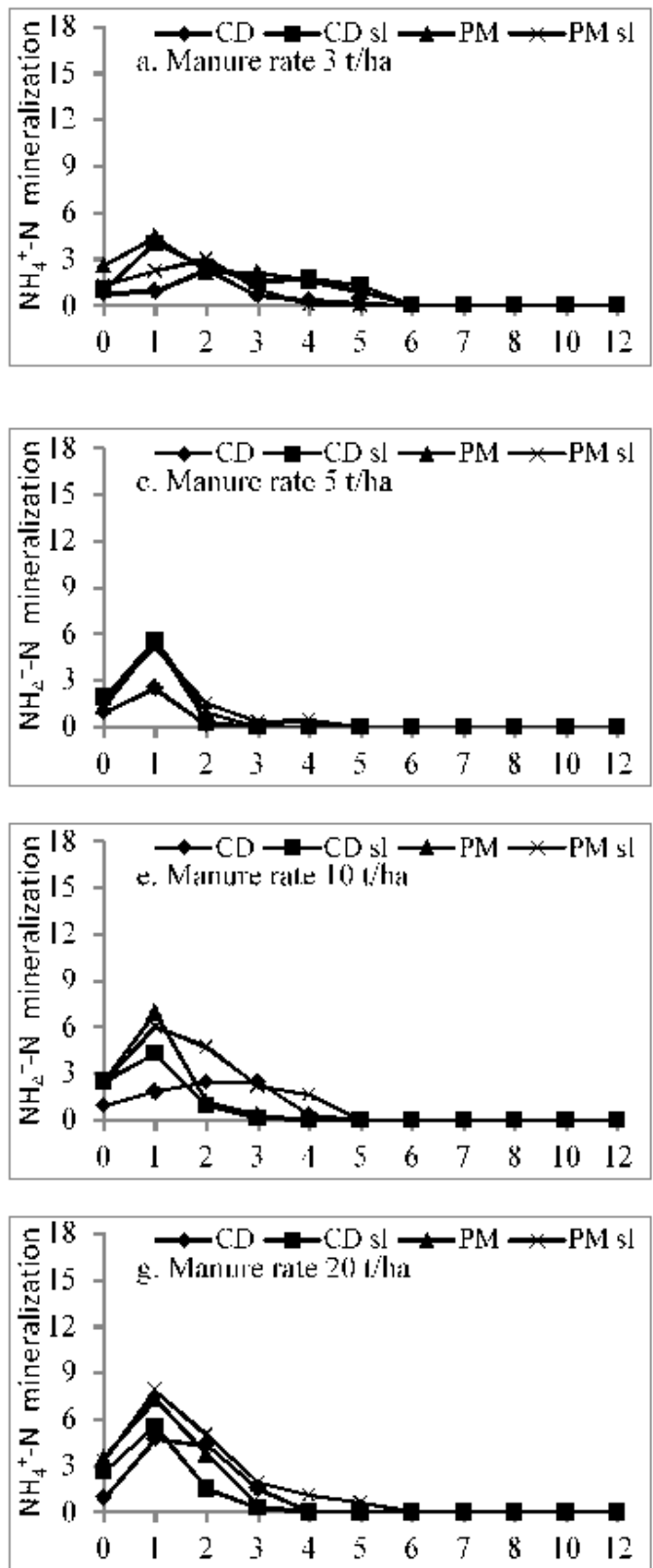

Weeks
Anaerobic condition
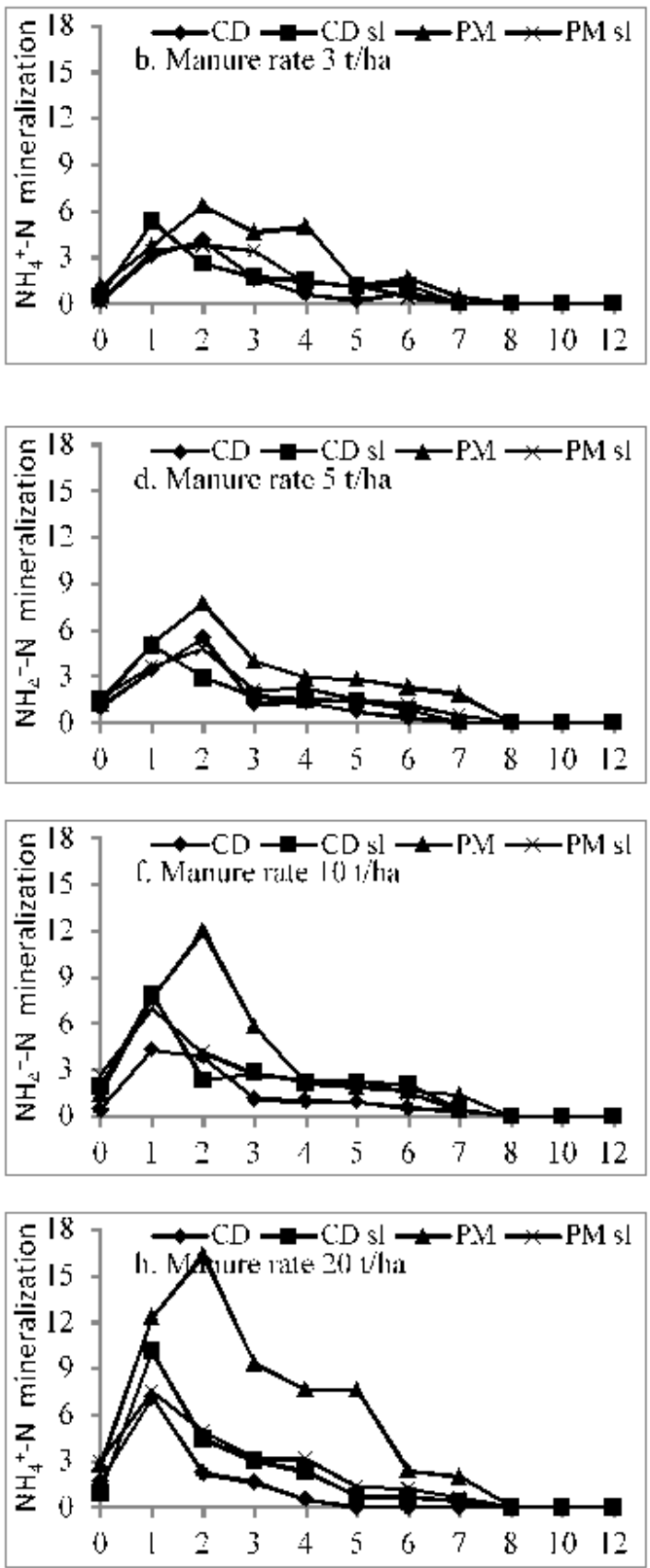

Weeks

Figure 1. Trend of net $\mathrm{NH}_{4}{ }^{+}-\mathrm{N}$ mineralization from different manures under aerobic and anaerobic conditions. Net mineralization is calculated as the difference in amount between manure and control

Concerning incubation period, all types of manure over the rates of manure use, the $\mathrm{NH}_{4}^{+}-\mathrm{N}_{\text {mineralization }}$ started from the first day of incubation under both aerobic and anaerobic conditions. However, under aerobic condition the $\mathrm{NH}_{4}{ }^{+}-\mathrm{N}$ mineralization reached its peak within the $1^{\text {st }}$ week with an exception in cowdung at 3 and $10 \mathrm{t} \mathrm{ha}^{-1}$ rate, where peak was reached in the $2^{\text {nd }}$ week, thereafter it declined gradually and went down to a negligible amount in 4 to 6 weeks (Fig.1 a, c, e and g). Under anaerobic condition, the scenario was different. In anaerobic condition, the $\mathrm{NH}_{4}{ }^{+}-\mathrm{N}$ mineralization increased progressively and attained its peak within $1^{\text {st }}$ to $2^{\text {nd }}$ 
week, then it decreased gradually and after 6-8 weeks the net $\mathrm{NH}_{4}{ }^{+}-\mathrm{N}$ mineralization was very low (Fig. 1. b, d, $f$ and h). Similar results were also described by Walpola and Arunakumara (2010) that the $\mathrm{NH}_{4}{ }^{+}-\mathrm{N}$ content reached to the peak at day-14 followed by gradual reductions in all the animal manure (poultry manure, goat manure and cowdung) treatments. The fluctuations of $\mathrm{NH}_{4}{ }^{+}-\mathrm{N}$ release during the incubation suggest that a possible loss of $\mathrm{NH}_{4}{ }^{+}-\mathrm{N}$ from the manure amended soil by means of $\mathrm{NH}_{3}$ volatilization. $\mathrm{NH}_{4}{ }^{+}-\mathrm{N}$ is therefore found as the dominant form of $\mathrm{N}$ under anaerobic soil condition. Maithani et al. (1998) and Calderon et al. (2004) also observed $\mathrm{NH}_{4}{ }^{+}-\mathrm{N}$ as the dominant form of inorganic $\mathrm{N}$ in anaerobic soils.

\section{$\mathrm{NO}_{3}-\mathrm{N}$ mineralization}

The trend of $\mathrm{NO}_{3}-\mathrm{N}$ mineralization under aerobic and anaerobic conditions is shown in Fig. 2. Across the manures under aerobic condition highest $\mathrm{NO}_{3}-\mathrm{N}$ mineralization in 3, 5, 10 and $20 \mathrm{t} \mathrm{ha}^{-1}$ rate was 23.8, 30.9, 38.9 and 49.7. $\mathrm{mg} \mathrm{kg}^{-1}$, which was $14.0,16.3,10.8$ and 27.7 times higher than that found in respective rates of manure under anaerobic condition. When cowdung or poultry manure were compared with their slurries, the bioslurry released markedly higher amount of $\mathrm{NO}_{3}-\mathrm{N}$ compared to cowdung and poultry manure, respectively. Amount of $\mathrm{NO}_{3}-\mathrm{N}$ from poultry manure bioslurry increased as the days of incubation increased till the last day of incubation indicating that poultry manure bioslurry has potential to long term $\mathrm{NO}_{3}{ }^{-} \mathrm{N}$ supply to soil. After 6-7 weeks, cowdung bioslurry also showed higher amount of $\mathrm{NO}_{3}^{-}-\mathrm{N}$ mineralization. Release of $\mathrm{NO}_{3}^{-}-\mathrm{N}$ from other manures went to its peak within 6-8 weeks of incubation and then it gradually decreased. Regarding rate of manure application, the $\mathrm{NO}_{3}^{-}-\mathrm{N}$ release increased with the increase of the rates of manure application.

The $\mathrm{NO}_{3}-\mathrm{N}$ mineralization was also strongly influenced by incubation period. Under both aerobic and anaerobic conditions the $\mathrm{NO}_{3}-\mathrm{N}$ mineralization in the initial days was very low. Under aerobic condition, with the passage of time the $\mathrm{NO}_{3}-\mathrm{N}$ mineralization increased progressively and reached its peak within 6-8 weeks and thereafter it showed decreasing trend (Fig. 2 a, c, e and g), but still after 12 weeks significant amount of $\mathrm{NO}_{3}{ }^{-}-\mathrm{N}$ was observed compared to their initial status. In anaerobic condition the scenario was found different showing that the amount of $\mathrm{NO}_{3}-\mathrm{N}$ release from different manures was small and for all manures, the peak value of $\mathrm{NO}_{3}-\mathrm{N}$ was attained within 2-4 weeks. After 6 weeks of incubation, practically the $\mathrm{NO}_{3}-\mathrm{N}$ disappeared from soil (Fig. 2; b, d, f and h). Thus, anaerobic condition was found not favorable for $\mathrm{NO}_{3}^{-}-\mathrm{N}$ availability in soil. In the present study, $\mathrm{NO}_{3}-\mathrm{N}$ was found to be the dominant form of inorganic $\mathrm{N}$ in aerobic soils.

\section{Cumulative total available $\mathrm{N}$ mineralization}

Cumulative total available $\mathrm{N}$ mineralization (calculated by addition of $\mathrm{NH}_{4}{ }^{+}-\mathrm{N}$ and $\mathrm{NO}_{3}{ }^{-}-\mathrm{N}$ ) from different manures under aerobic and anaerobic conditions is presented in Fig. 3. It is clearly evident that under aerobic condition cumulative $\mathrm{N}$ mineralization was found much higher compared to anaerobic condition. Among the manures under the study, cowdung bioslurry showed the highest cumulative $\mathrm{N}$ mineralization for all rates of manure use except $20 \mathrm{t} \mathrm{ha}^{-1}$ under aerobic soil condition. Both poultry manure and poultry manure bioslurry had cumulative $\mathrm{N}$ mineralization very close to cowdung bioslurry. At $20 \mathrm{t} \mathrm{ha}^{-1}$ manure rate under aerobic condition, poultry manure bioslurry demonstrated the highest cumulative $\mathrm{N}$ mineralization. Cowdung consistently released lower amount of $\mathrm{N}$ in soil. Under aerobic environment, the $\mathrm{N}$ mineralization was found to increase with the increasing rates of manure application (Fig. $3 \mathrm{a}, \mathrm{c}$, e and g), but under anaerobic condition the cumulative $\mathrm{N}$ mineralization was unaffected by the different types of manure and also by the different rates of manures (Fig. $3 \mathrm{~b}, \mathrm{~d}, \mathrm{f}$ and $\mathrm{h}$ ). When highest cumulative total available $\mathrm{N}$ mineralization at $3,5,10$ and $20 \mathrm{t} \mathrm{ha}^{-1}$ rate was considered after 12 weeks of incubation, it was found that $N$ mineralization was 5.0, 5.5, 6.8 and 4.3 times higher in aerobic condition over respective anaerobic condition, respectively. Cordovil et al. (2007) reported that among the manures poultry manure was the most efficient $\mathrm{N}$ supplier compared to municipal solid waste compost for crops. Okonkwo et al. (2011) noted the pattern of $\mathrm{N}$ mineralization as poultry dropping $>$ sewage sludge $>$ goat dropping >cowdung > control. In the experiment poultry manure bioslurry and cowdung bioslurry performed better compared to poultry manure and cowdung, respectively probably due to lower $\mathrm{C}: \mathrm{N}$ ratio of the manures. 
Aerobic condition
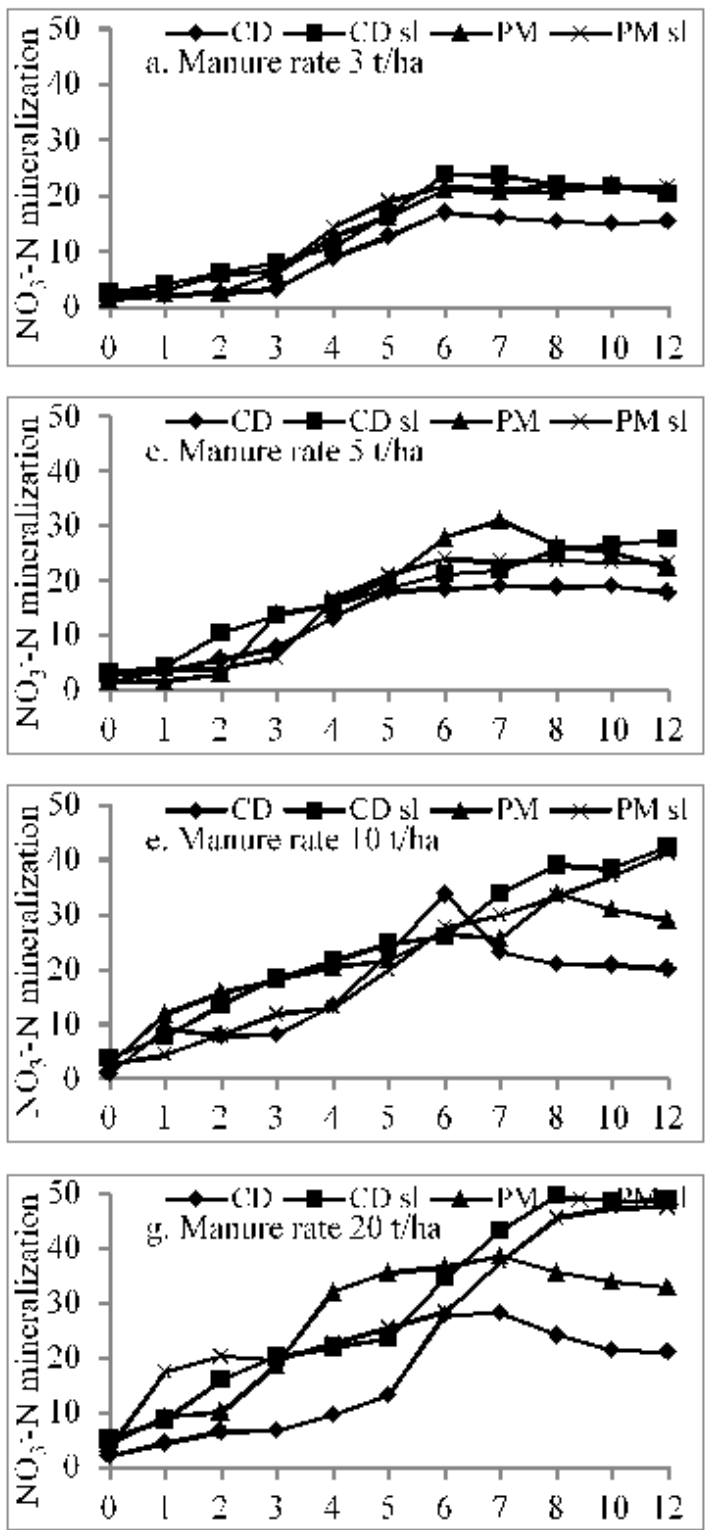

Weeks

\section{Anaerobic condition}
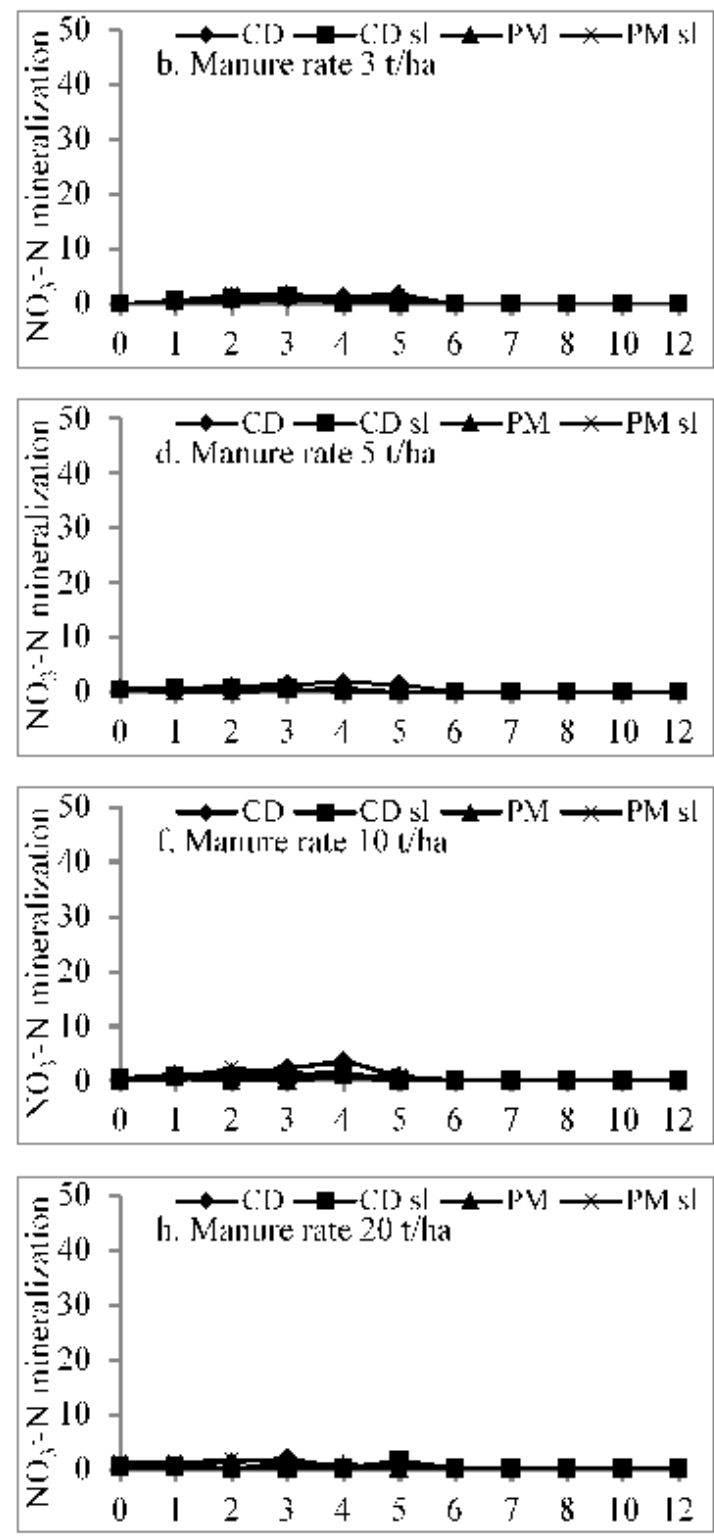

Weeks

Figure 2. Trend of net $\mathrm{NO}_{3}^{-}-\mathrm{N}$ mineralization $\left(\mathrm{mg} \mathrm{kg}^{-1}\right)$ from different manures under aerobic and anaerobic conditions. Net mineralization is calculated as the difference in amount between manure and control

\section{Percent $\mathbf{N}$ mineralization}

The amount of $\mathrm{N}$ addition through manure incorporation, maximum total available $\mathrm{N}$ mineralization and percent of total added $\mathrm{N}$ mineralization is presented in Table 2. Based on maximum total available $\mathrm{N}$ mineralization value the highest percent $\mathrm{N}$ release at $3 \mathrm{t} \mathrm{ha} \mathrm{A}^{-1}$ was 66.7, 86.2, 64.0 and 84.3 in cowdung, cowdung bioslurry, poultry manure and poultry manure bioslurry, respectively. This rate in $5 \mathrm{t} \mathrm{ha}^{-1}$ was $44.7,60.0,54.2$ and 56.2 and that of 39.5, 46.0, 29.6 and 48.6 in $10 \mathrm{t} \mathrm{ha}^{-1}$ and was 16.6, 27.0, 16.9 and $28.0 \%$ in $20 \mathrm{t} \mathrm{ha}^{-1}$ rate, respectively. Under anaerobic condition, similar trend was observed, but the extent was much lower compared to aerobic condition. Lower $\mathrm{N}$ release in anaerobic condition was probably occurred due to lower decomposition of organic manure in soil. Table 2 further indicates that under aerobic condition cowdung bioslurry and poultry 
manure bioslurry had very closer percent $\mathrm{N}$ mineralization and was much higher compared to their original manure (cowdung and poultry manure). Across the kinds of manure, with the increase of the rate of manure application maximum total available $\mathrm{N}$ release was increased but percent $\mathrm{N}$ release was rather decreased with the increase of manure rate irrespective of the types of manure and soil moisture contents (Table 2). Such observation was valid for all manures under both aerobic and anaerobic conditions.

Aerobic condition
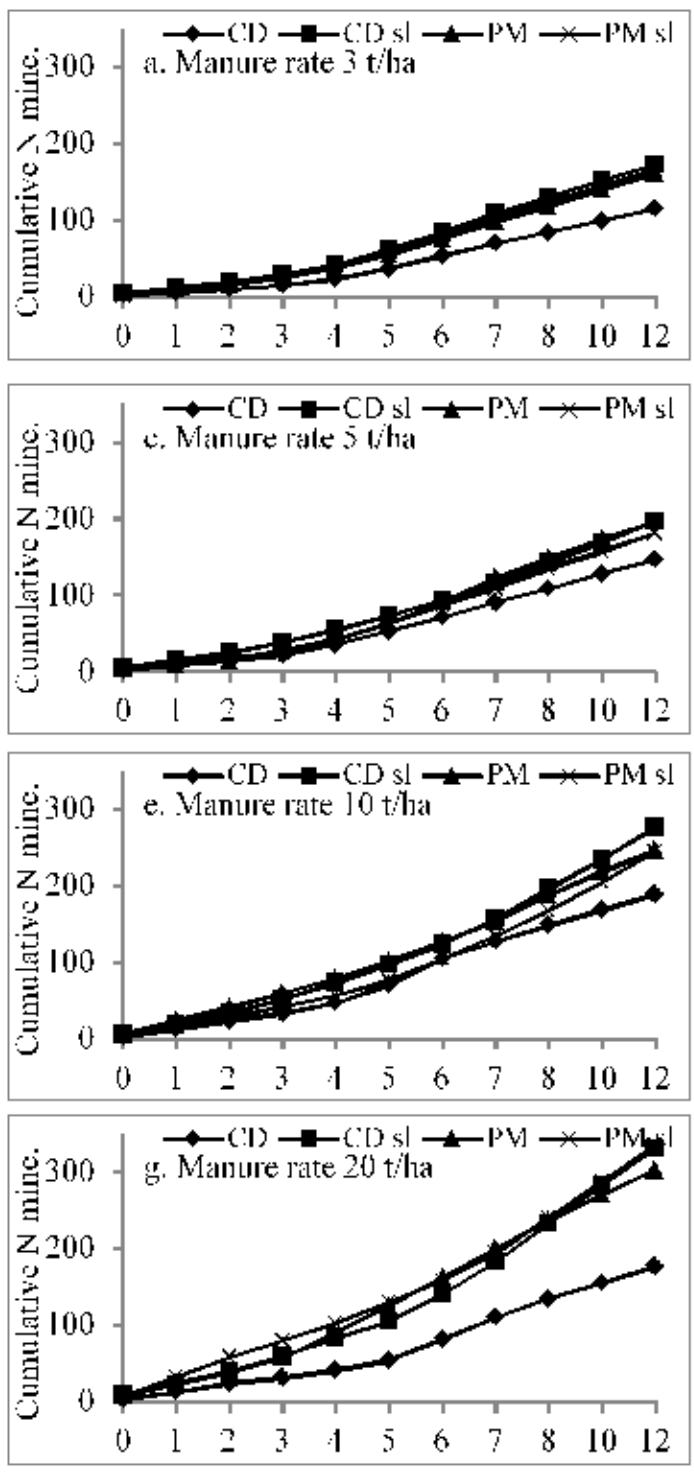

Weeks

\section{Anaerobic condition}
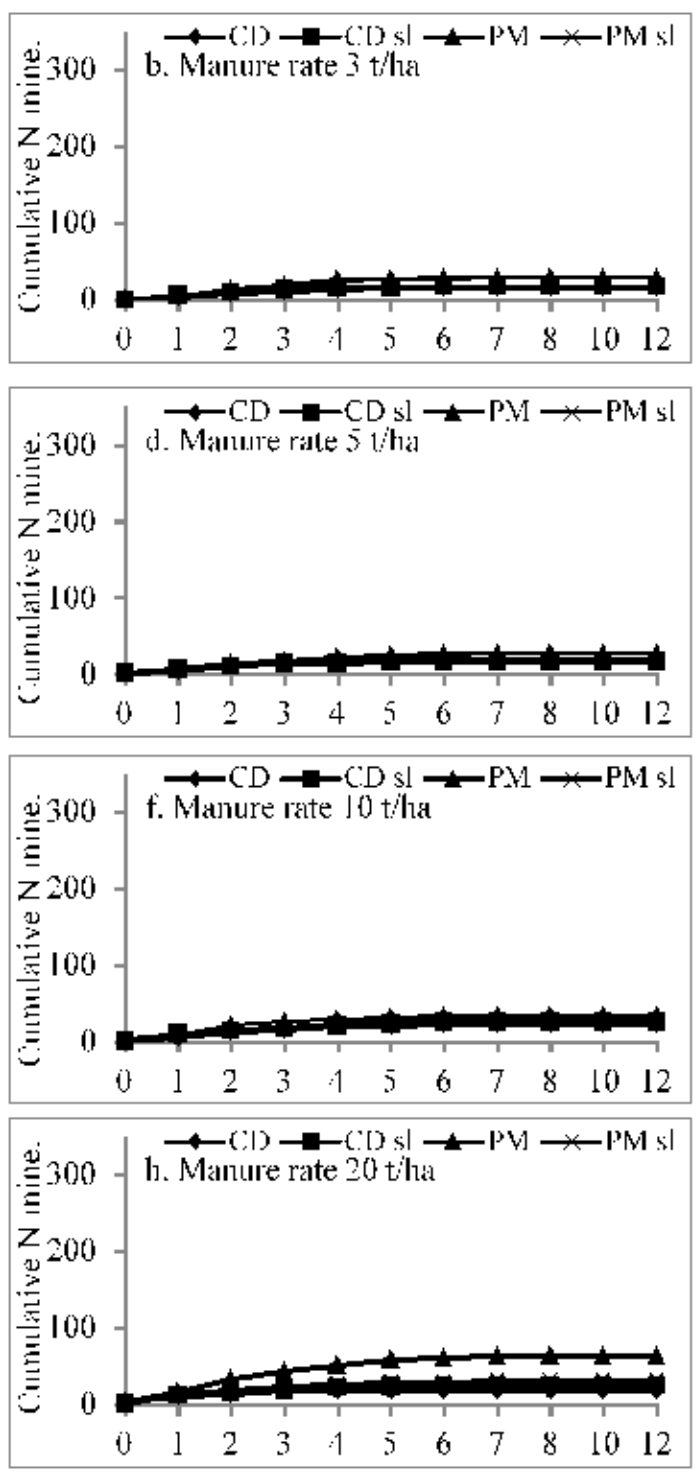

Weeks

Figure 3. Trend of cumulative $\mathrm{N}\left(\mathrm{NH}_{4}{ }^{+}-\mathrm{N}+\mathrm{NO}_{3}^{-}-\mathrm{N}\right)$ mineralization $\left(\mathrm{mg} \mathrm{kg}^{-1}\right)$ in soil during decomposition of manures under aerobic and anaerobic conditions

The percent $\mathrm{N}$ mineralization was higher for the lower rates of manure application and it gradually decreased with the increase of the rate of manure application. The reduction rate was always higher in aerobic condition compared to anaerobic condition. Every soil probably have ability to mineralize $\mathrm{N}$ in a specific rate, beyond this limit the applied organic manures are accumulated in the soil. This result otherwise indicates that higher rate of manure application might leave some $\mathrm{N}$ for the preceding crops in the cropping system. 


\section{CONCLUSION}

Bioslurries, whether it is cowdung or poultry manure, had higher percentage of $\mathrm{N}$ mineralization compared to their original manure (cowdung and poultry manure, respectively). Nitrogen mineralization in aerobic condition was higher and faster compared to anaerobic condition. Bioslurries can be advised to use as manure in parallel with cowdung and poultry manure for crop production.

\section{ACKNOWLEDGEMENT}

This work was supported by the World Bank funded Higher Education Quality Enhancement Project (HEQEP) implemented in the Department of Soil Science, Bangladesh Agricultural University, Mymensingh.

\section{REFERENCES}

1. Abubaker J. 2012. Effects of fertilization with biogas residues on crop yield, soil microbiology and greenhouse gas emissions. Acta Universitatis Agriculturae Sueciae, Department of Microbiology, Swedish University of Agricultural Sciences, 46: 1-79.

2. Brady NC and RC Weil, 2013. The nature and properties of soils. Dorling Kindersley (India) Pvt. Ltd. $14^{\text {th }}$ ed. pp 545-548.

3. Calderon FJ, GW McCarty, JA Van-Kassel and JB Reeves, 2004. Carbon and nitrogen dynamic during incubation of manured soil. Soil Science Society of America Journal, 68:1592-99.

4. Chaudhary DR, J Chikara and A Ghosh, 2014. Carbon and nitrogen mineralization potential of biofuel crop (Jatrophacurcas L.) residues in soil. Journal ofSoil Science and Plant Nutrition, 14(1) online version http://dx.doi.org/10.4067/S0718-95162014005000002

5. Cordovil CMDS, F Cabral and J Coutinho, 2007. Potential mineralization of nitrogen from organic wastes to ryegrass and wheat crops. Bioresource Technology, 98: 3265-68.

6. Islam M F. 2011. Bioslurry: An untapped black gold. http://www.biocompostbd.blogspot.com

7. Karim Z, MMU Miah and S Razia, 1994. Fertilizer in the national economy and sustainable environmental development. Asia Pacific. Journal of Environment and Development, 2: 48-67.

8. Keeney DR and DW Nelson, 1982. Methods of Soil Analysis, Part 2, (A. L. Page et al.) $2^{\text {nd }}$ edn. Agronomy 9, ASA \& SSSA, Madison, Wiscosin, p 643.

9. Maithani K, AArunachalam, RS Tripathi and HN Pandey, 1998. Influence of leaf litter quality on N mineralization in soils of subtropical humid forest re-growths. Biology and Fertility of Soils, 27:44-50.

10. Okonkwo CI, JN Nwite, Onyibe C, IA Nweke and C N Mbah, 2011. Animal manures mineralization and plant nitrogen uptake in an ultisol in Abakaliki Southeast Nigeria. Journal of Agriculture and Biological Sciences, 2: 123-128.

11. Page AL, RH Miller and DR Keeney, 1982. Methods of Soil Analysis. American Society of Agronomy, Inc. and Soil Science Society of America, Inc. Madison, Wisconsin.

12. Rahman MM. 2010. Carbon sequestration options in soils under different crops and their management practices. The Agriculturists, 8: 90-101.

13. Rahman MM. 2014. Carbon and nitrogen dynamics and carbon sequestration in soils under different residue management. The Agriculturists, 12: 48-55.

14. Walpola BC and KKIU Arunakumara. 2010. Effect of salt stress on decomposition of organic matter and nitrogen mineralization in animal manure amended soils. The Journal of Agricultural Sciences, 5: 9-18.

15. Yu FB, XP Luo, CF Song, MX Zhang and SD Shan. 2010. Concentrated bioslurry enhanced soil fertility and tomato quality. Plant Soil Science, 60: 262-68. 